\title{
VÁROSI FELSZÍN PARAMETRIZÁCIÓK SZEREPE ÉS HATÁSA A LEVEGÖMINÖSÉG BECSLÉSÉRE BEÉPÍTETT KÖRNYEZETBEN
}

\author{
Kovács Attila ${ }^{(1)}$ (D), Leelőssy Ádám ${ }^{(1)}$ (D), Mészáros Róbert ${ }^{(1)}$ (D), Lagzi István László ${ }^{(2)}$ (iD \\ ${ }^{(1)}$ Eötvös Loránd Tudományegyetem, Meteorológiai Tanszék \\ 1117 Budapest, Pázmány Péter sétány 1/A. \\ ${ }^{(2)}$ Budapesti Müszaki és Gazdaságtudományi Egyetem, Fizika Intézet \\ 1111 Budapest, Budafoki út 8. \\ e-mail: kovacsattila0318@gmail.com, leelossyadam@gmail.com, \\ mrobi@nimbus.elte.hu, istvanlagzi@gmail.com
}

\section{Bevezetés}

A levegőminőség előrejelzése összetett feladat, hiszen az áramlási mező mellett számos légszennyező kibocsátását, kémiai reakcióit és ülepedését is figyelembe kell vennünk (Kovács et al., 2019). Egészségtelen levegőminőség leggyakrabban városi környezetben, vagy annak közvetlen közelében figyelhető meg, mivel az ilyen területeken a legnagyobb az antropogén kibocsátás. A numerikus modellezés szempontjából fontos a városi felszín parametrizációja, ami befolyásolja a beépített területeken létrejövő áramlási viszonyokat, amik kihatnak a modell által számított koncentrációértékekre (Chen et al., 2011). Jelen kutatásunkban a városi felszín parametrizációk hatását vizsgáljuk a felszínközeli ózon koncentrációra a WRF-Chem (Weather Research and Forecasting coupled with Chemistry, v4.0) (Peckham et al., 2012) csatolt regionális időjárás-elörejelző és kémiai transzport modell segítségével, különböző városi felszín-modell alkalmazásával készített szimulációkat összehasonlítva egymással.

\section{Modellbeállítások}

Szimulációs területként három modelltartományt állítottunk be: a Közép-Európa méretü legkülső (d01); az első beágyazott, Magyarországot reprezentáló (d02); valamint a legbelső, Budapestet és környékét magába foglaló régiót (d03). A horizontális rácsfelbontások rendre 15,5 és $1 \mathrm{~km}$-esek voltak (1. ábra). Vertikálisan 40 szinttel számolt a modell.

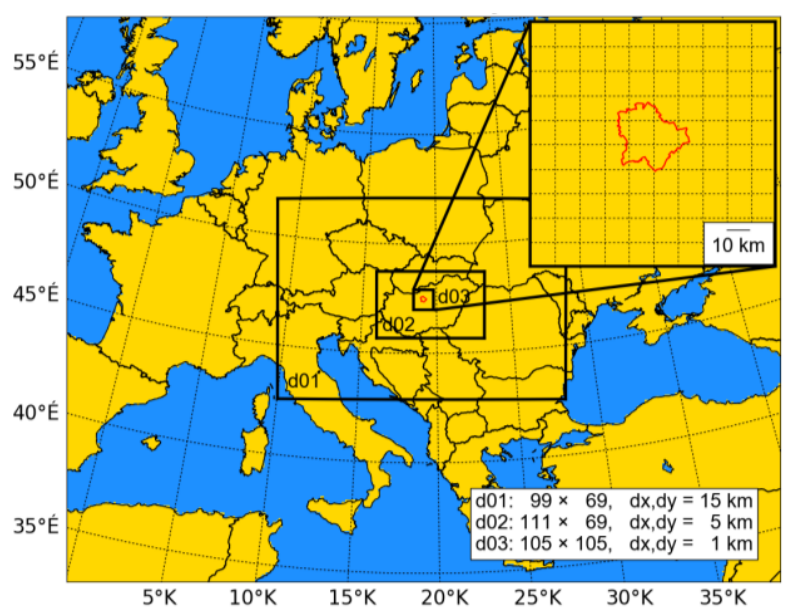

1. ábra: A WRF-Chem három egymásba ágyazott modelltartománya. 
A modell előfeldolgozó rendszere minden cellára megadja a felszínhasználati kategóriákat (2. ábra), így képes a modell figyelembe venni a különböző felszínek feletti albedókat, levélfelületi indexeket és érdességi paramétereket. A szimulációkhoz az USGS (United States Geological Survey) adatbázisa által meghatározott besorolást használtuk fel, a városi felszínparametrizáció változtatása pedig természetesen csak a városi és beépített területekre (1-es kategória) volt hatással.

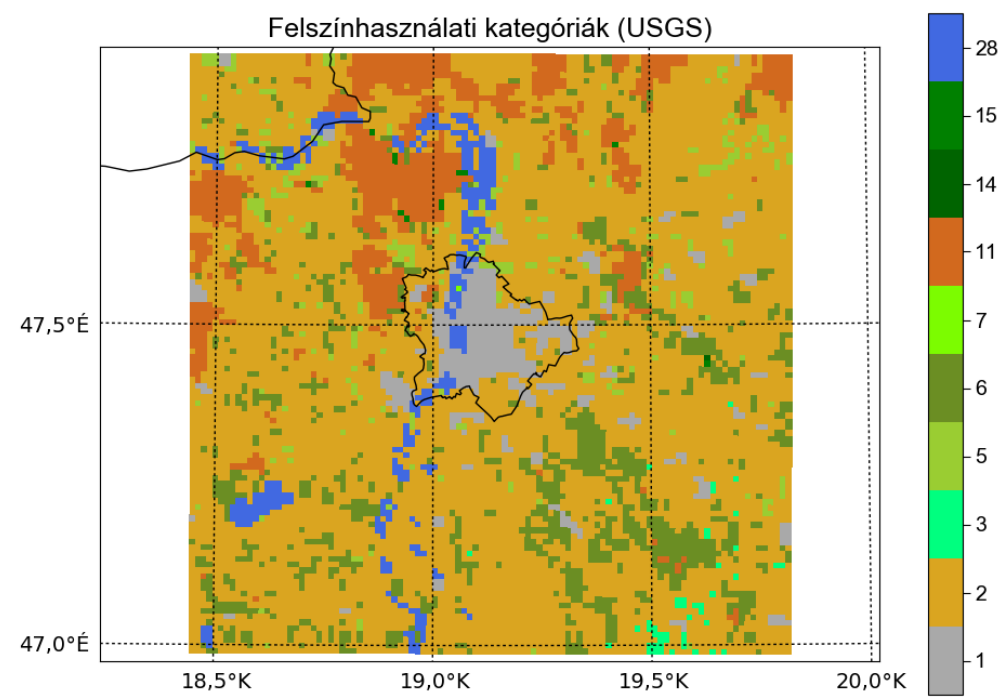

2. ábra: A felszínhasználati kategóriák a legbelső modelltartományra.

A WRF-Chem modellt ugyanazon időszakra, ugyanolyan beállításokkal futtattuk le, kizárólag a városi felszín parametrizációt változtattuk meg. A szimulációs időszak négy napból állt 2015. május 6. és 9. között, ahol az első nap a felpörgési (vagy spin-up) időt jelentette, az időjárási helyzetet pedig egy hidegfront utáni gyenge áramlási viszonyokat mutató, csapadékban szegény időszak jellemezte a vizsgált napokban. A modellbeállítások az 1. táblázatban foglaltuk össze.

1. táblázat: A szimulációk során a WRF-Chem modellben használt sémák.

\begin{tabular}{|l|l|}
\hline Mikrofizika & WRF Single-Moment 6-class séma \\
\hline Rövidhullámú sugárzás & Régi Goddard séma \\
\hline Hosszúhullámú sugárzás & Rapid Radiative Transfer Model (RRTM) \\
\hline Felszíni réteg & $\begin{array}{l}\text { Módosított NCAR Mesoscale Model } \\
\text { Monin-Obukhov séma (Revised MM5) }\end{array}$ \\
\hline Planetáris határréteg & Bougeault and Lacarrère séma (BouLac) \\
\hline Felszíni folyamatok & Noah Land Surface Model (Noah LSM) \\
\hline \multirow{2}{*}{ Kémiai folyamatok } & $\begin{array}{l}\text { Második generációs Regional Acid } \\
\text { Deposition Model (RADM2) }\end{array}$ \\
\hline \multirow{3}{*}{ Városi felszín } & 1.) Single Layer Urban Canopy Model (SLUCM) \\
\cline { 2 - 2 } & 2.) Building Environment Parameterization (BEP) \\
\cline { 2 - 2 } & 3.) Building Energy Model (BEM) \\
\hline
\end{tabular}

\section{Városi felszín parametrizációk}

A WRF-Chem modellben három beépített városi felszín almodell található. A legegyszerübb ezek közül az ún. egyszintü városi felszín modell (Single Layer Urban Canopy Model, 
SLUCM, 3. ábra). Ez a modell csak egy szinttel rendelkezik, egyetlen átlagos épületmagasságot tekint, és az épületek feletti érdességi alréteget, valamint az ez alatti városi felszíni réteget a legalsó modellszintbe állítja be (Kusaka \& Kimura, 2004). Az SLUCM általános szélsebesség-profilt használ, a szenzibilis hőáramok tekintetében figyelembe veszi az épületek tetejét, falait és az utakat, az épületek által képzett kanyonokban pedig az árnyékolást, illetve a sugárzás visszaverődését és elnyelődését is képes szimulálni.

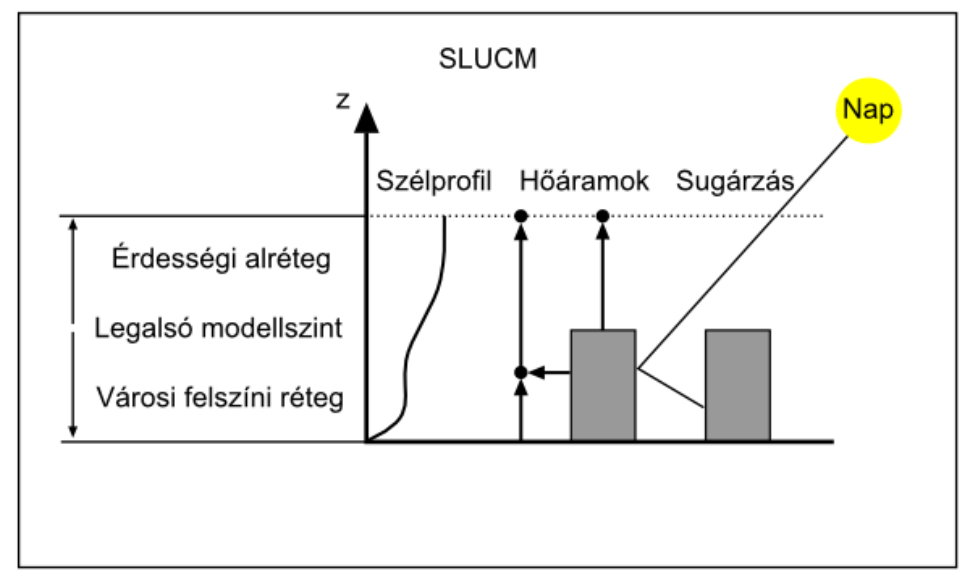

3. ábra: Az egyszintủ városi felszín modell sematikus ábrája (Chen et al., 2011, Fig 2. alapján).

A második beállítási lehetőség az épület-környezet parametrizáció (Building Environment Parameterization, BEP, 4. ábra), amely az épületeket már különböző magasságokkal adja meg, ami összetettebb hatást gyakorol az áramlási viszonyokra, a turbulenciára és a sugárzásra (Martilli et al., 2002).

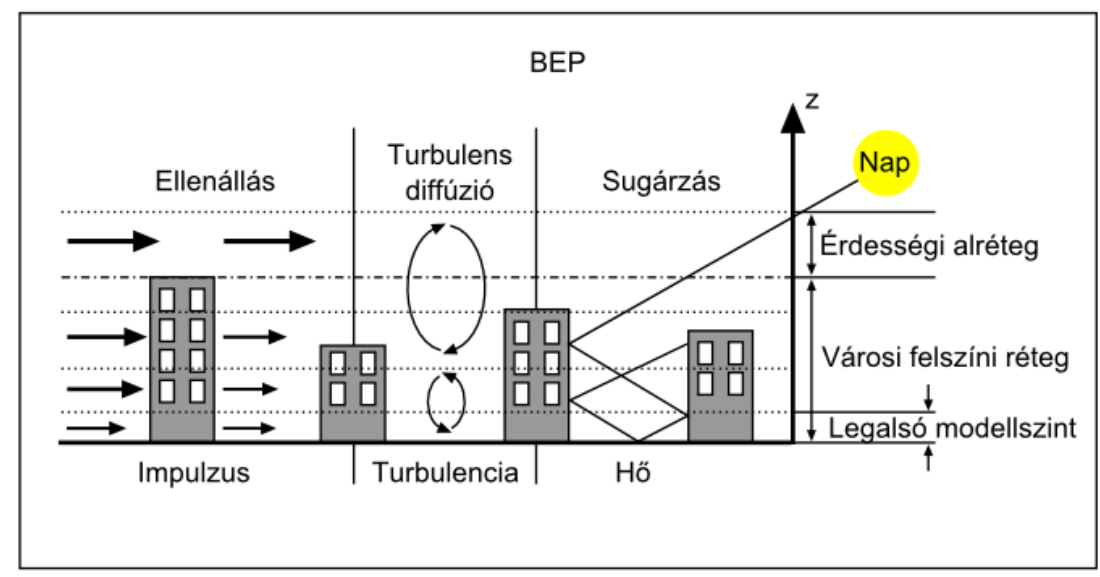

4. ábra: A többszintủ városi modell sematikus ábrája (Chen et al., 2011, Fig 2 alapján).

A harmadik városi felszín parametrizáció az épületenergetikai modell (Building Energy Model, BEM), amely a BEP modell kiegészítése olyan energetikai hatásokkal, mint a fütés, a légkondicionálás, vagy a padlón és az ablakokon keresztül történő hőcsere (Salamanca et al., 2010).

\section{Emisszió}

A bemenő emissziós adatokhoz az EMEP (European Monitoring and Evaluation Programme) kataszteréből származó, 2015-re vonatkozó emissziós értékeket használtuk fel. A $0,1^{\circ} \times 0,1^{\circ}$ 
horizontális felbontású kibocsátási adatokat (5.ábra) térbeli interpoláció segítségével a modell $1 \mathrm{~km} \times 1 \mathrm{~km}$ horizontális rácsfelbontású legbelső tartományának legalsó vertikális modellszintjére állítottuk be. A másodlagos légszennyező (vagyis a ki nem bocsátott, de levegőkémiai reakciók során képződő) ózon modellben való megjelenéséhez annak prekurzorait: a szén-monoxidot $(\mathrm{CO})$, a nitrogén-oxidokat $(\mathrm{NO})$, valamint a különböző (nem metán) illékony szerves vegyületeket (NMVOC) adtuk meg a modell számára. A nitrogénoxid emisszió megadásakor, amely magába foglalja a nitrogén-monoxid (NO) és a nitrogéndioxid $\left(\mathrm{NO}_{2}\right)$ kibocsátást, az összetevő-arány ismeretének hiányában 50-50\%-os megoszlást alkalmaztunk. Az NMVOC emissziójának esetében az összetétel szintén ismeretlen volt, ezért ezt a kibocsátást izoprénként adtuk meg a bemenő emissziós mezőben.
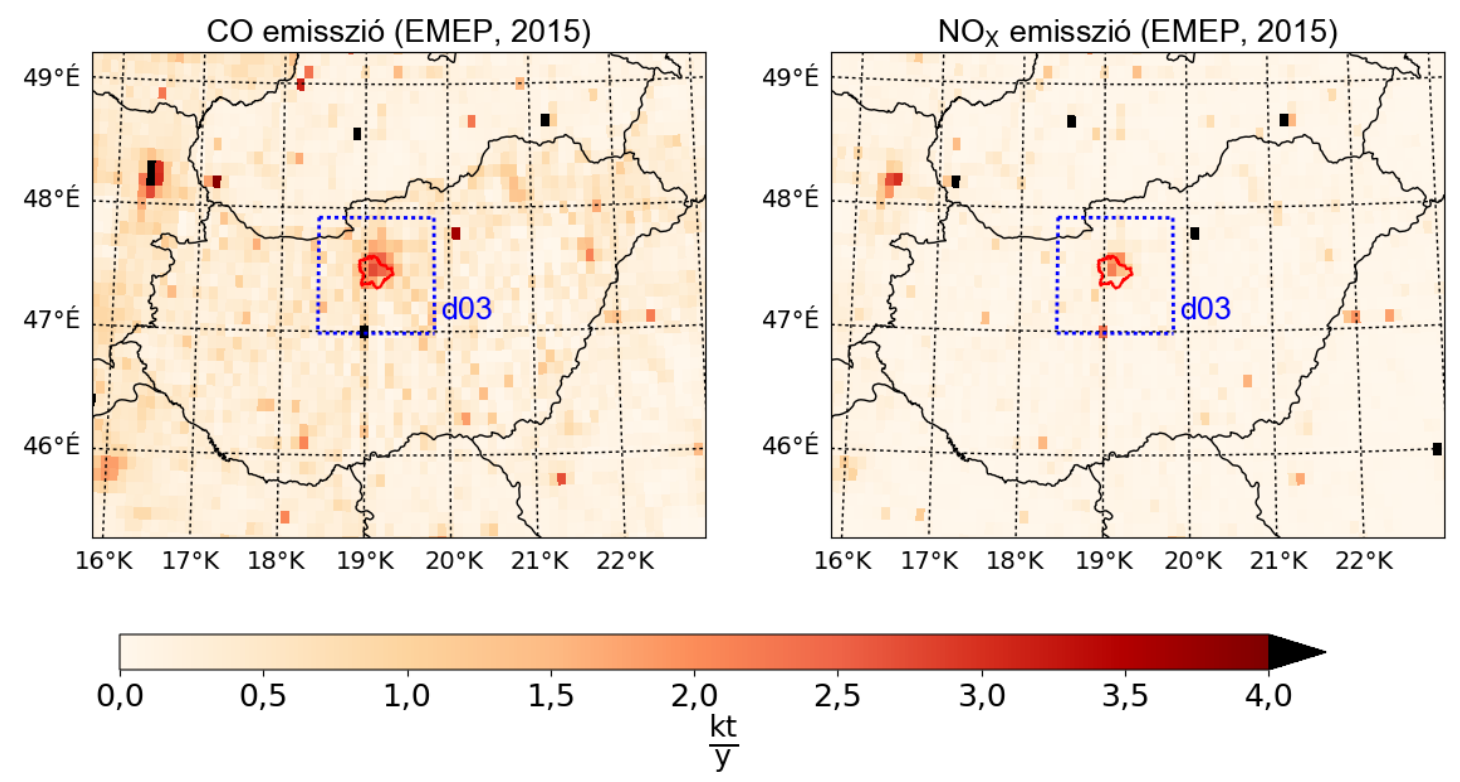

5. ábra: Az EMEP adatbázis szén-monoxid (bal oldal) és nitrogén-oxid (jobb oldal) emissziós mezői 2015-re kilotonna/év mértékegységekben.
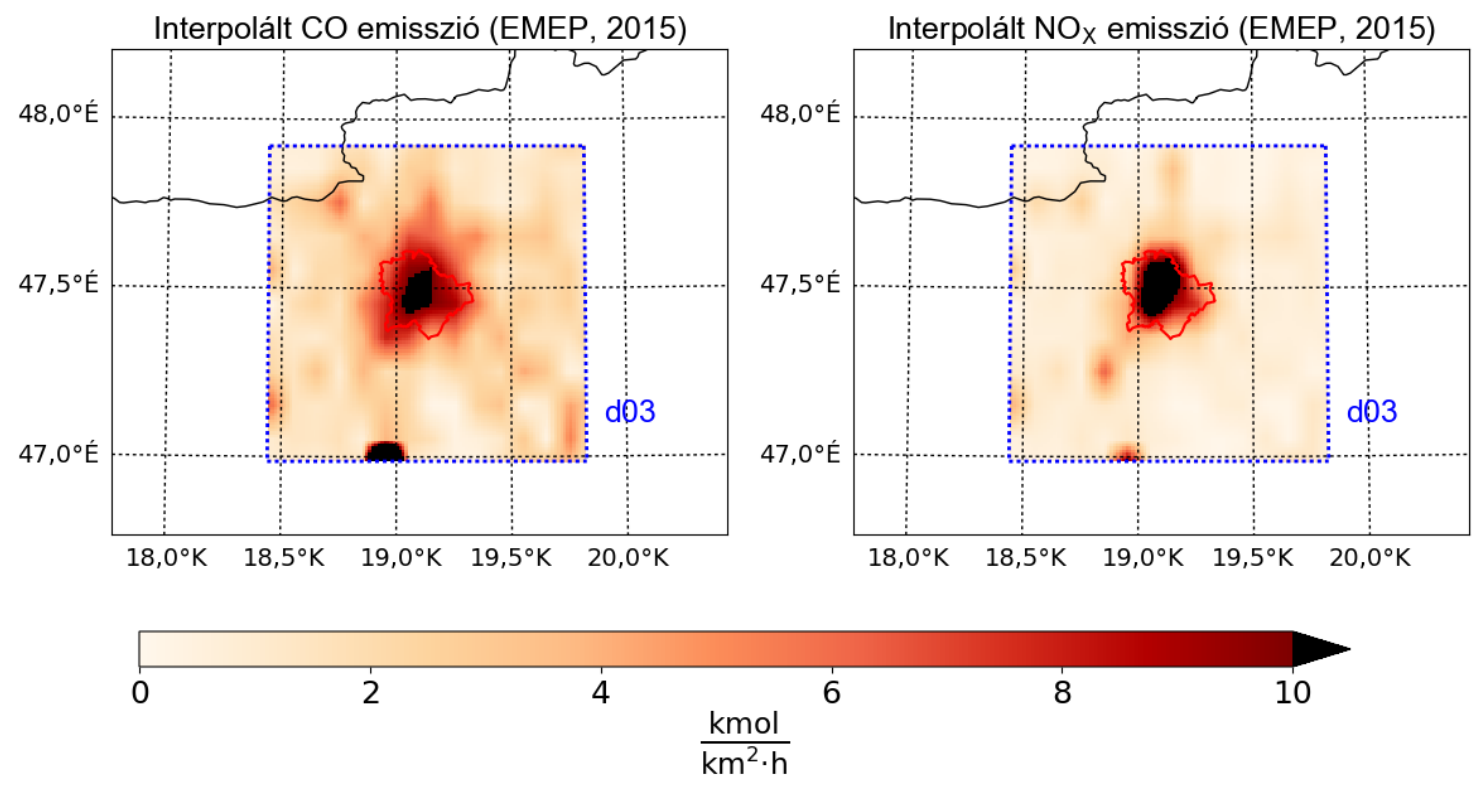

6. ábra: Az EMEP adatbázis szén-monoxid (bal oldal) és nitrogén-oxid (jobb oldal) interpolált emissziós mezői 2015 -re kilomol/( $\mathrm{km}^{2}$ óra $)$ mértékegységekben. 
Az emissziós térképeken jól kivehetők a nagyvárosok, illetve jól látszik az is, hogy a kisebb települések főként fütésből származó szén-monoxid kibocsátása jelentősebb, mint a közlekedési és ipari forrásokból adódó nitrogén-oxid emissziója.

Mivel az EMEP emissziós adatai éves értékek, és nem rendelkeznek időbeli menettel, ezért a legegyszerübb közelítéssel élve minden órára az éves érték 8 760-ad (órák száma egy évben) részét állítottuk be. Az interpolált emissziós mezőkön (6. ábra) is kivehető a jelentősebb közlekedéssel járó nagyobb nitrogén-oxid kibocsátás Budapest területén, valamint a dunaújvárosi ipari létesítmények erőteljes hatása.

\section{Eredmények}

A szimulált ózonkoncentrációk összehasonlításához kivontuk egymásból a különböző városi felszín parametrizációkkal készített modelleredményeket. A többszintes és az egyszintes (7. ábra), valamint a többszintes épületenergetikai és az egyszintes (8. ábra) városi modellel készített szimulációk ózonkoncentrációjának különbsége nagyon hasonló képet mutatott. A szimulációk 2015. május 8-án 14 UTC-re (7. ábra) erős besugárzást és gyenge, északias áramlási mezőt jeleztek előre. A Budapest területén látható negatív értékek a BEP/BEM modellek alacsonyabb, illetve az SLUCM modell magasabb ózonkoncentrációját jelölik, ami egy északról dél felé irányuló transzport következménye. Ugyanakkor nagyobb szélsebességek esetén (22 UTC, 8. ábra) a városoknál megfigyelt koncentrációkülönbségek pozitívak, vagyis a BEP/BEM modellek feltehetőleg mélyebb kanyonokat alakított ki városi környezetben, mint a SLUCM modell város-parametrizációja, amely ennél kisebb ellenállást szimulált az áramlás szempontjából.

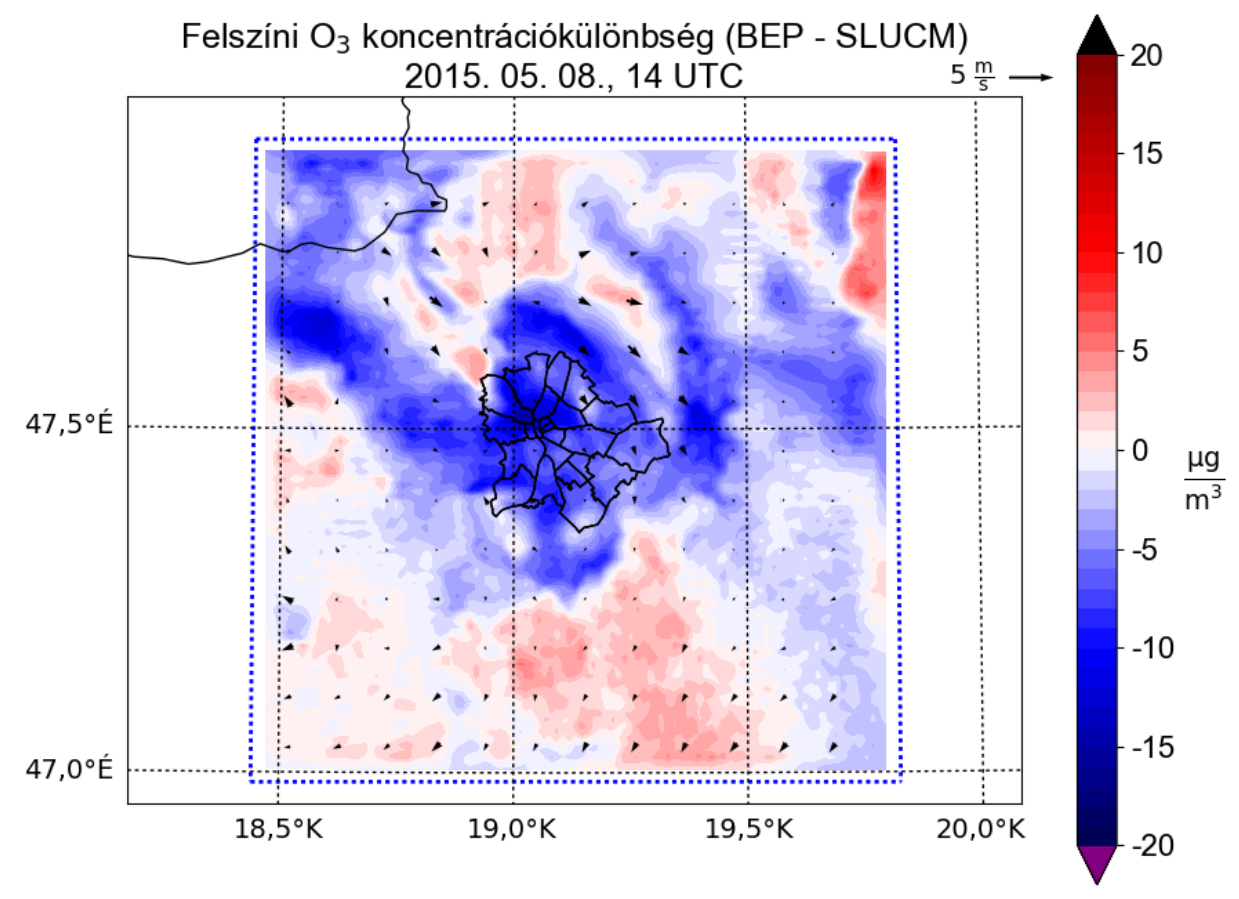

7. ábra: Felszíni ózonkoncentráció-különbség (BEP - SLUCM) 2015. május 8-án 14 UTC-kor. 


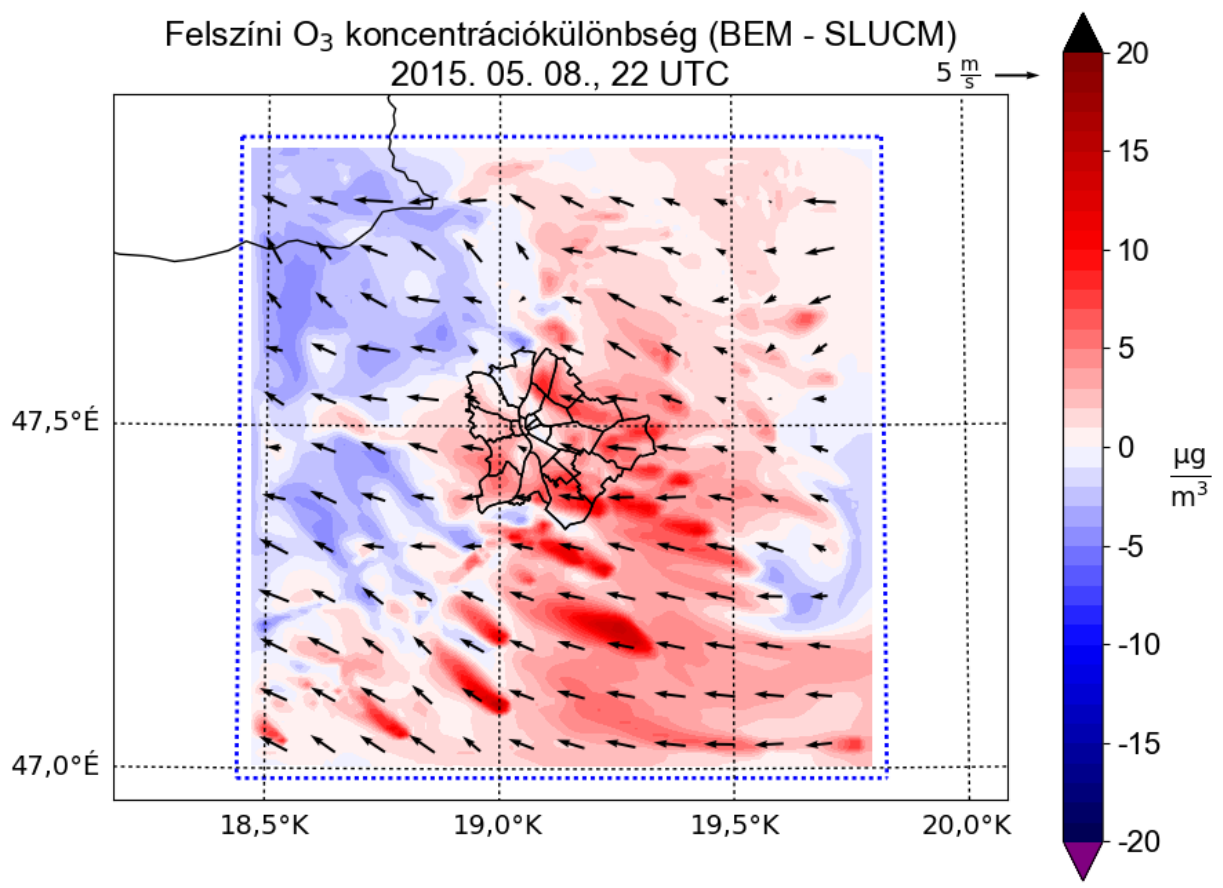

8. ábra: Felszíni ózonkoncentráció-különbség (BEM - SLUCM) 2015. május 8-án 22 UTC-kor.

Végül megvizsgáltuk az épületenergetikai parametrizáció hatását az ózonkoncentrációra (9. ábra). Az eltérések itt már nem annyira érzékenyek az áramlási mezőre, és csak néhány $\mu \mathrm{g} / \mathrm{m}^{3}$ nagyságrendüek. Viszont a különbségek jellemzően pozitívak, azaz a BEM modell nagyobb értékeket jelzett elöre, mint a BEP parametrizáció, amely pusztán az épületenergetika által módosított turbulens keveredés eltérésének eredménye.

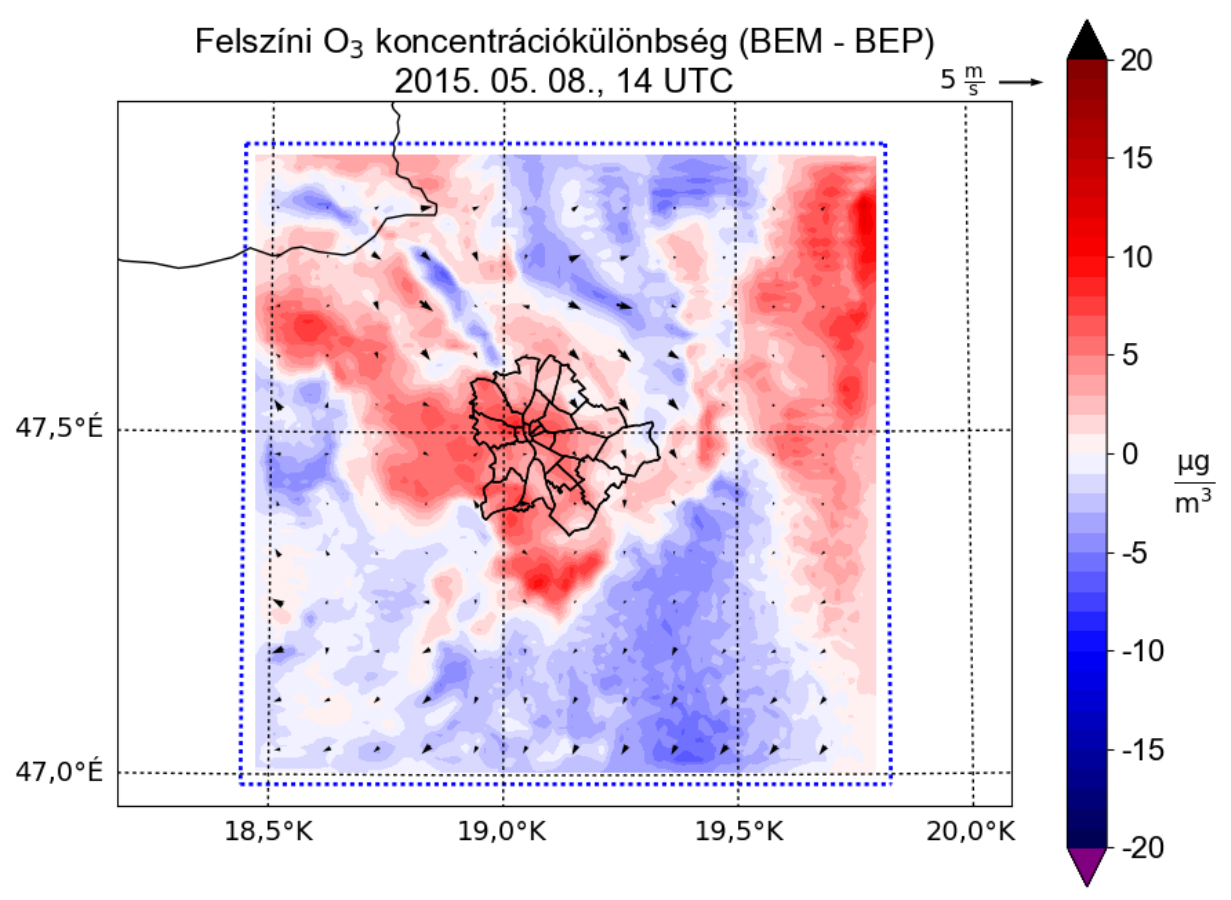

9. ábra: Felszíni ózonkoncentráció-különbség (BEM - BEP) 2015. május 8-án 14 UTC-kor. 


\section{Összefoglalás}

Kutatásunk során azt tapasztaltuk, hogy a légszennyezők felszíni koncentrációi kizárólag a városi felszín parametrizáció változtatása mellett is eltérnek egymástól. Ezek a különbségek $70 \mu \mathrm{g} / \mathrm{m}^{3}$-es átlagos ózonkoncentráció esetén elérték akár a $\pm 10 \mu \mathrm{g} / \mathrm{m}^{3}$-es értéket is. Megfigyelhető továbbá, hogy nagyobb szélsebességek nagyobb eltéréseket hoznak létre, ami az eltérő épület-, és utcaparaméterek miatt létrejött különböző mértékü ellenállásoknak tulajdonítható. Az emissziós mező fejlesztésével a szimulációk pontosabbakká válhatnak, de ehhez érzékenységvizsgálatok és további parametrizációk szükségesek, ugyanis a kibocsátás nehezen mérhető mennyiség, időbeli menete nehezen írható le, kiváltképp finom felbontás mellett.

Köszönetnyilvánítás: A kutatásokat a Nemzeti Kutatási, Fejlesztési és Innovációs Alap K128805, K116506 és K-128818 pályázatai támogatták.

\section{Hivatkozások}

Chen, F., Kusaka, H., Bornstein, R., Ching, J., Grimmond, C.S.B., Grossman-Clarke, S., Loridan T., Manning, K.W., Martili, A., Miao, S., Sailor, D., Salamanca, F.P., Taha, H., Tewari, M., Wang, X., Wyszogrodzki, A., Zhang, C., 2011: The integrated WRF/urban modelling system: development, evaluation, and applications to urban environmental problems. International Journal of Climatology, 31(2): 273-288. https://doi.org/10.1002/joc. 2158

Kovács, A., Leelössy, Á., Mészáros, R., Lagzi, I., 2019: Online coupled modeling of weather and air quality of Budapest using the WRF-Chem model. Idöjárás, 123(2): 203-215. DOI:10.28974/idojaras.2019.2.5

Kusaka, H., Kimura, F., 2004: Coupling a single-layer urban canopy model with a simple atmospheric model: Impact on urban heat island simulation for an idealized case. Journal of the Meteorological Society of Japan. Ser. II, 82(1): 67-80. https://doi.org/10.2151/jmsj.82.67

Martilli, A., Clappier, A., Rotach, M. W., 2002: An urban surface exchange parameterisation for mesoscale models. Boundary-layer Meteorology, 104(2): 261-304. https://doi.org/10.1023/A:1016099921195

Peckham, S.E., et al., 2011: WRF-Chem Version 3.3 User's Guide. US Department of Commerce, National Oceanic and Atmospheric Administration, Oceanic and Atmospheric Research Laboratories, Global Systems Division. 40. kötet/NOAA technical memorandum OAR GSD. pp. 94.

Salamanca, F., Krpo, A., Martilli, A., Clappier, A., 2010:. A new building energy model coupled with an urban canopy parameterization for urban climate simulations - part I. formulation, verification, and sensitivity analysis of the model. Theoretical and Applied Climatology, 99(3-4): 331. https://doi.org/10.1007/s00704-009-0142-9

\section{ORCID}

Kovács A. (D) https://orcid.org/0000-0002-8087-7093

Leelössy A. (D) https://orcid.org/0000-0001-9583-0127

Mészáros R. iD https://orcid.org/0000-0002-0550-9266

Lagzi I. (D) https://orcid.org/0000-0002-2303-5965 